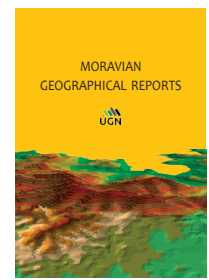

The Czech Academy of Sciences, Institute of Geonics

journal homepage: http://www.geonika.cz/mgr.html

doi: https://doi.org/10.2478/mgr-2020-0011

\title{
From service areas to empty transport corridors? The impact of border openings on service and retail facilities at Polish-Czech border crossings
}

\author{
Marek FURMANKIEWICZ $^{\text {a }}$, Krzysztof BURYŁ0 ${ }^{\text {a }}$, Sylwia DOŁZBŁASZ ${ }^{\text {b }}$
}

\begin{abstract}
Long-term changes in the development of service establishments in the vicinity of the border crossing points on the Polish-Czech border are discussed in this paper. These changes are the result of the border being opened and subsequent economic integration. A series of panel studies, which took place in 1995, 2000 and 2016, analysed of the locations and types of service establishments located within a half kilometre of 18 Polish-Czech border crossings. Given the increasing ease of crossing the border and the maintenance of passport and customs controls, the number of service and retail establishments increased until 2000. After the abolition of passport control in 2007, this number has decreased at many border crossings, with the most significant decreases in financial, insurance-related and commercial facilities (small shops). Most crossings have become little more than transport corridors that offer no important service functions. The total number of cultural, recreational and tourismrelated establishments, however, has increased, mainly at border crossings located in towns and villages. The most important changes in service developments at the Polish-Czech border are discussed, as well as the probable reasons for these changes. The results may prove useful for spatial planning in municipalities that are located on the borders of countries undergoing political and economic integration.
\end{abstract}

Key words: economic integration, border opening, border crossings typology, transport corridors, service and retail outlets, Polish-Czech border

Article history: Received 31 December 2019, Accepted 25 May 2020, Published 30 June 2020

\section{Introduction}

The impact that changes in national borders can have on adjoining areas is one of the established topics in geographic research (Jones, 1959; Minghi, 1963; Prescott, 1965). One important factor in such border changes is how geopolitical conditions affect the de-bordering processes. The geopolitical integration taking place across Europe in recent decades may be the most significant issue in this context, since, along with the democratisation that took place in post-socialist Central and Eastern European countries in the 1990s, it has contributed to radical changes in the functioning of political borders. From a practical standpoint, eliminating the control functions of border crossings at many national boundaries, including the one between Poland and the Czech Republic, is particularly important (Kolejka et al., 2015; Kolosov and Więckowski, 2018).
In 2007, three years after Poland and the Czech Republic joined the European Union (EU), border controls between the two countries were abolished. Opening the border made it possible to enter the neighbouring state at practically any point on the countries' shared border. This, in conjunction with the construction of new roads allowing for open car travel across the border, resulted in a significant increase in border permeability and traffic dispersion, since there was no longer any need to stop at a border crossing point. The integration process has had significant impacts in many respects, one of which relates to retail development in local border areas: free cross-border mobility has led to the decline of shopping and service establishments in the vicinity of border crossings.

Although border studies are of great interest to researchers in various disciplines - resulting in a multitude of studies and publications in this field - there have been few

\footnotetext{
a Institute of Spatial Economy, The Faculty of Environmental Engineering and Geodesy, Wroclaw University of Environmental and Life Sciences, Poland (*corresponding author: M. Furmankiewicz, e-mail: marek.furmankiewicz@ upwr.edu.pl)

${ }^{\mathrm{b}}$ Department of Spatial Management, Institute of Geography and Regional Development, University of Wrocław, Poland
} 
analyses of spatial development in terms of infrastructure and service functions at and/or near border crossings (with the exception of divided cities) (e.g. Cosaert, 1994; Davis and Friske, 2013; Khan, 2010; Miltiadou et al., 2017). This is particularly true for post-socialist countries such as those in East Central Europe (e.g. Dołzbłasz and Zelek, 2019; Furmankiewicz, 2000). Most existing research centres on issues of general socioeconomic development in border areas, encompassing tourism (e.g. Kladivo et al., 2012; Krätke, 1996; Ladysz, 2006; Máliková et al., 2014; Pászto et al., 2019; Potocki et al., 2014; Stryjakiewicz, 1998; Więckowski, 2010) and various forms of cross-border cooperation, also in the context of 'Euroregions' (e.g. Böhm and Drápela, 2017; Dołzbłasz and Raczyk, 2010; Furmankiewicz, 2005, 2007; Kaczmarek, 2006; KurowskaPysz and Szczepańska-Woszczyna, 2017; Pipan, 2007; Turnock, 2002; Yoder, 2003).

Noteworthy studies on how transport accessibility, crossborder movement and shopping, impact neighbouring areas in the context of border permeability include: Kolejka et al. (2015), Komornicki (1999), Komornicki and Wiśniewski (2017), Kulczyńska (2018), Mackré (2008), Pászto et al. (2019), Rosik (2012) and Vaishar et al. (2013), with respect to Polish borders; and Capello et al. (2018), Fullerton and Walke (2019), Studzińska et al. (2018) and Szytniewski et al. (2017), for other countries' borders. There are relatively few analyses dedicated to the spatial issues of cross-border trade and services, however, nor to entrepreneurial approaches to targetting customers from the neighbouring country. With regard to the Polish-Czech border, these include Böhm and Opioła (2019), Dołzbłasz (2015), Kulczyńska (2018), Kulczyńska and Matykowski (2008) and Powęska (2008, 2016).

It should be pointed out that there is a research deficit when it comes to studies focusing on managing land uses in the vicinity of border crossings, especially in relation to service functions and changes observed over the long term. As such, the analyses undertaken in this paper, taking the Polish-Czech border as an example, present a contribution to the domain of services development in connection with border crossings, in particular with regard to studying how such functions change over time. The results of the analyses may prove useful for theoreticians involved in studies of the impact of border permeability changes on surrounding areas.

The aim of this paper is to analyse changes in the number of retail and service providers, as well as their structural types, located within a half-kilometre of former passport border control points between 1995 and 2016. The authors aimed to identify the most significant features in terms of which service providers were found in the vicinity of border crossings, as well as any changes that had taken place over this time period in relation to border permeability, as well as the decrease in social and economic differences between Poland and the Czech Republic.

The analysis also offers a comparison with contemporary economic activity in the immediate vicinity of these border crossings, taking into account trade (commercial outlets), gastronomic facilities, financial and insurancerelated services, etc., as well as an overview of changes in the structure and spatial distribution of facilities on the Polish and Czech sides of the border. We use a comparative approach to analyse the phenomena of cross-border services using a framework of symmetry and asymmetry, looking at changing dynamics and interrelations.
It also needs to be noted that research findings related to this topic - that is, changes in the development of the service infrastructure at former border crossings caused by border openings - may have potential applications in the spatial planning of borderland municipalities. This applies particularly to EU states that are planning to - but have not yet - joined the Schengen Agreement: at the time of writing this article, this would be applicable to the RomanianHungarian and Bulgarian-Greek borders, for example. The work may also be practically relevant to other countries planning to gradually reduce or eliminate border controls as a result of political and economic integration.

\section{Border permeability and border crossings from a theoretical perspective}

Research on borders and border areas is a longstanding area of study within many scientific disciplines, including geography and economics (Prescott, 1965; Newman, 2003a). The existence and management of inter-state border crossings and the conditions for crossing them are of great importance to a society and its economy. When analysing businesses operating in border areas, two issues seem particularly important: the role and function of the border itself; and phenomena related to cross-border shopping mobility (Boonchai and Freathy, 2020; Fullerton and Walke, 2019; Studzińska et al., 2018).

According to Rietveld (2012), a border assumes the form of a place or line within a certain space in which one observes a sudden drop in the intensity of interactions between two or more places. This contention is explained by five types of the barrier effects of borders:

1. Consumer preferences for domestic products or travel destinations;

2. National regulations, such as taxes, visas for foreign visitors or other legal constraints;

3. Different public and private institutions on both sides of the border (or different management centres);

4. Lack of information about foreign countries; and

5. Higher transport or communication costs related to crossing the border.

Acting as a barrier is an essential feature of a political boundary, and it is therefore important to analyse its permeability (Komornicki, 1999, 2004). The degree to which a border functions as a barrier depends on numerous factors, including geographic, economic and political issues. Since borders are subject to change (Anderson and O'Dowd, 1999; Nicol and Minghi, 2005), especially with regard to their functions, so too are the phenomena and long-term processes related to their influence. One wellknown study by Martinez (1994) divides borders into four types of borderland: alienated, coexistent, interdependent and integrated. According to this author, these categories are not completely disjunctive, however, and it is usual for one to be dominant. The characteristics of frontiers can be related to either 'de-bordering' or 're-bordering' processes (e.g. Blatter, 2001; Nelles and Durand, 2014; Newman, 2006; Popescu, 2011; Scott and Van Houtum, 2009; Scott, 2011; Van Houtum and Van Naerssen, 2002). The contemporary definition of 'bordering' is very broad: it is a multidimensional phenomenon encompassing trans-border relations that are personal, familial and professional, but that are also related to both local and central governance regulating border-related matters. The classic meaning of 
'bordering,' on the other hand, regards it as a process of defining and controlling the boundaries of sovereign states (Newman, 2003b).

It should be noted that, due to the evolution of the concept of the border and diverse research approaches to the subject, it is currently thought that a border may constitute a kind of 'resource,' which can also provide opportunities for development and yield beneficial outcomes (Agnew, 2008; Gerber et al., 2010; Heffner, 1998; Knotter, 2014; Martinez, 1994; Reitel, 2006; Sohn, 2014; Sohn and LaraValencia, 2013; Timothy, 1995; Timothy and Gelbman, 2015; Van der Velde and Spierings, 2010). One example is seen in a border's ability to generate border shopping (Anisiewicz and Palmowski, 2014; Boonchai and Freathy, 2020; Fullerton and Walke, 2019; Studzińska et al., 2018). It is important to note that borders can have both positive and negative effects simultaneously (Dołzbłasz, 2015). Under particular economic and political conditions, for example during advanced integration processes, the role of the border as barrier may be lessened; but as a rule, its negative effects cannot be entirely avoided (Ackleson, 2005). Eliminating barriers usually yields a positive outcome for the functioning of border areas, e.g. by serving as a stimulus for economic growth. It may also have negative consequences (Dołzbłasz, 2017). As observed by Spierings and Van der Velde (2008), removing borders and, in turn, levelling the economic differences between neighbouring areas, may result in the eradication of interactions between local inhabitants, for example those who partake in trans-border shopping or tourism.

In particular, border crossing points primarily serve a control function. They constitute a selective barrier to the movement of people and goods. On the other hand, they are also gateways facilitating international trade (Anderson and O'Dowd, 1999; Davis and Friske, 2013; Phillips, 2005). Borders typically have a greater effect on passenger travel than on freight transport (Rietveld, 2012), requiring that vehicles stop en route (Khan, 2010; Miltiadou et al., 2017). This contributes to the development of retail and service outlets in the immediate vicinity of these border crossings, from food businesses to commercial services, as well as external customs, insurance and financial services such as currency exchanges. Increased traffic may accelerate the development of these businesses, but, simultaneously, opening up a border and eliminating the requirement for vehicles to stop may result in the closure of some service outlets. A decrease in border effects is typical for bordering EU countries undergoing integration (Rietveld, 2012).

The barrier and contact functions of a border cannot be separated: borders divide two political, social and economic systems, but they also bring them into contact with one other (Popescu, 2011; Prescott and Triggs, 2008). Border crossings or, more broadly areas which allow the crossing of national boundaries, are fundamental elements that enable the socio-economic merging of border areas. This is directly reflected in the way that surrounding areas are managed and how economic activity develops in these places.

The symmetry vs. asymmetry framework is a vital tool in examining neighbouring border areas and trans-border relations (Dołzbłasz and Raczyk, 2017; Holly et al., 2003). The problem of trans-border cooperation is discussed often in the existing literature, but another relevant element is trans-border mobility, for example in terms of the fulfilment of service and shopping-related needs. When examining experiences at various border areas across Europe, it becomes clear that consumers prefer to fulfil their elementary shopping needs in their home countries. Differences in availability and pricing, as well as the cultural aspects of any given product, are the only incentives to cross a border in order to make a purchase (Studzińska et al., 2018; Szytniewski et al., 2017). This phenomenon - of high levels of economic independence on both sides of a border - can be observed even in border areas where two countries have long-standing EU cooperation, or in places where the border is not a significant physical or cultural barrier (Bygvrã and Westlund, 2004).

Nevertheless, the phenomenon of consumer mobility is commonly observed across political borders in frontier regions. Trans-border flows, which are directly associated with the existence of a border, have a practical dimension and material output in, among other areas, spatial management and service function development in borderlands. There are two opposing tendencies that simultaneously increase and decrease consumer mobility. Trans-border flows are increased by 'pull factors' such as attracting a neighbouring populace to a different country, and 'push factors,' which motivate people to leave their home country. There can be some reductions by 'keep factors', which discourage the populace from leaving their home country, and 'repel factors', which discourage people from visiting a neighbouring country (Spierings and Van der Velde, 2008). Many studies have confirmed that notable physical and psychological differences between populations on different sides of a border can have a negative impact on cross-border interaction (Van Houtum, 1999). Cross-border mobility, however, is often stimulated by the attractiveness of an area that is located on the other side of a border, and ideas to visit that area in order to experience something new and different. For this reason, efforts to diminish the dividing role of a border although they are often positive and result in increased integration - paradoxically contribute to decreased interest in visiting a neighbouring country because of the lack of novelty (Spierings and Van der Velde, 2008).

These various effects can also be accompanied by a 'blurring' of the differences between border areas that reduces incentives to cross the border. As Leimgruber (2005, p. 245) points out, cross-border shopping practices are commonly asymmetric, which is a consequence of the differences between one side of the border and the other. More importantly, however, these differences are not static and are subject to change.

Studies on the presence of service facilities in the vicinity of border crossings (conducted as part of this research) are one part of the larger discussion about how state boundaries can have impacts on the phenomena that accompany crossborder mobility. Our current multi-year research project, which examines the number of such services as well as their typological structure, allows us to identify and evaluate changes over time in the symmetries and asymmetries at the Polish-Czech border. These changes are the result of the evolution of the conditions surrounding the border and the role it plays as a barrier.

\section{Materials and methods}

The field studies, which are based on a consistentlyworded instrument, were conducted in 1995, 2000 and 2016 and encompassed 18 border crossings and the Cieszyn/Český Těšín town centre (Tab. 1).

The 1995 study included 18 border crossings that were only accessible to passport-holding pedestrian or automobile 
Important dates and the year that research took place (in bold)
Description of border permeability from the points of view of Polish and Czech citizens

1988: Abolition of socialist restrictions on Polish citizens obtaining Partially closed border, accessible only with permits/visas passports

1990: First democratic Parliamentary elections in Czechoslovakia

1991: Polish-Czechoslovak agreement on visa-free travel (abolishing The border is open at border crossings only for people with passports; the requirement for an invitation or visas to cross the border) and customs restrictions on the transport of goods remain until 2004 first democratic Parliamentary elections in Poland

1993: Peaceful dissolution of Czechoslovakia into the Czech Republic and Slovakia

\section{5: First series of field studies}

1996: Polish-Czech agreement to open new, small border crossings for borderland inhabitants and tourist border crossings on hiking and cycling routes

2000: Second series of field studies (panel research)

2004: Polish and Czech accession to the European Union

Abolition of customs controls

2005: Schengen Agreement signed by Poland and the Czech Republic

2007: Abolition of permanent border control in the borderlands analysed in this study

Abolition of permanent passport control, allowing people to cross the border at any point (excluding locally restricted areas, such as nature reserves and roads closed to the public)

2016: Third series of field studies (panel research)

Tab. 1: Chronology of the research on border crossing/services in the context of major historical events affecting border permeability (see Section 4)

Source: Compiled by the authors using historical data

traffic (and thus accessible to researchers from further afield without the need for additional permits). For the subsequent study years, the authors used a panel research method: no new border crossings (opened after 1995) were included, because we wanted to ensure long-time data comparability ${ }^{1}$. The western part of the analysed border is located in the Sudetes (Sudety Mountains), which form a natural barrier and are characterised by a relatively low population density (Fig. 1). The eastern part is located in the lowland industrial region of Silesia and has the highest population density in this study area. The eastern edge of the area is located in the Beskid Mountains (Beskidy).

Two former passport border crossings in the centre of the divided city of Cieszyn/Český Těšín (at the Wolności bridge and the Przyjaźni bridge, respectively) were excluded from our detailed analysis because they are completely different kinds of border crossings. They are located in the centre of a city that was artificially divided by a border after World War I. For this reason, they are located in completely different surroundings than the other crossings, which are most commonly located in rural or extra-urban areas (sometimes near towns), as well as mountainous regions. Moreover, although the two border bridges in Cieszyn/Český Těšín are located only 500 metres from one another, they were once formally treated as one border crossing with two one-way passages; currently, they constitute two separate, two-way crossings. Consequently, in order to make the study data comparable, the Cieszyn/Český Těšín border crossing points were not taken into consideration in the main analysis; however, some data about this divided city are incorporated into our results section.
The number of service establishments that provided commercial, gastronomic and other types of services (located in buildings or making use of mobile stands, etc.) have been documented within a 500-metre radius of the border control zone, since control typically occurred in the vicinity of, but not precisely on the geographical border. This study exclusively involved areas linked by roads. All types of service facilities were documented and classified according to three major research categories used by the authors:

- Retail outlets: classified into non-durable locations (such as mobile stands and easily movable kiosks), durable grocery and general stores, durable industrial stores and other durable locations (specifically, large-area stores like hypermarkets ${ }^{2}$, wholesale stores, shopping malls, marketplaces and car dealerships).

- Gastronomic facilities: classified into standard eating places (e.g. restaurants, bars, cafés offering confections) and small ones, most of which are non-durable (e.g. mobile fast food and grill stands, small corner shops, and locations such as hot-dog counters in grocery stores).

- Other service establishments: defined as any businessrelated, professional or governmental facility providing substantial services and involving direct contact with clients. These were classified as follows: 1) finance (e.g. currency exchange booths, bank branches, private customs services); 2) insurance (e.g. insurance broker points); 3) culture, recreation and tourism (e.g. tourist information and travel agencies, hotels, private accommodation, culture centres and museums, sport centres); and 4) other (e.g. public administration, schools, civic associations, post offices, medical services, fuel stations, etc.).

\footnotetext{
${ }^{1}$ This work expands upon and refines the 2000 analysis by Furmankiewicz (which was published in Polish), using data on border crossings that were collected as part of his master's thesis (Furmankiewicz, 1996), as well as similar work by one of the coauthors of this article (Buryło, 2017).

2 The Polish Act, which relates to the creation and operation of large-format commercial facilities, defines hypermarkets as stores with an area of trade larger than 400 square metres.
} 


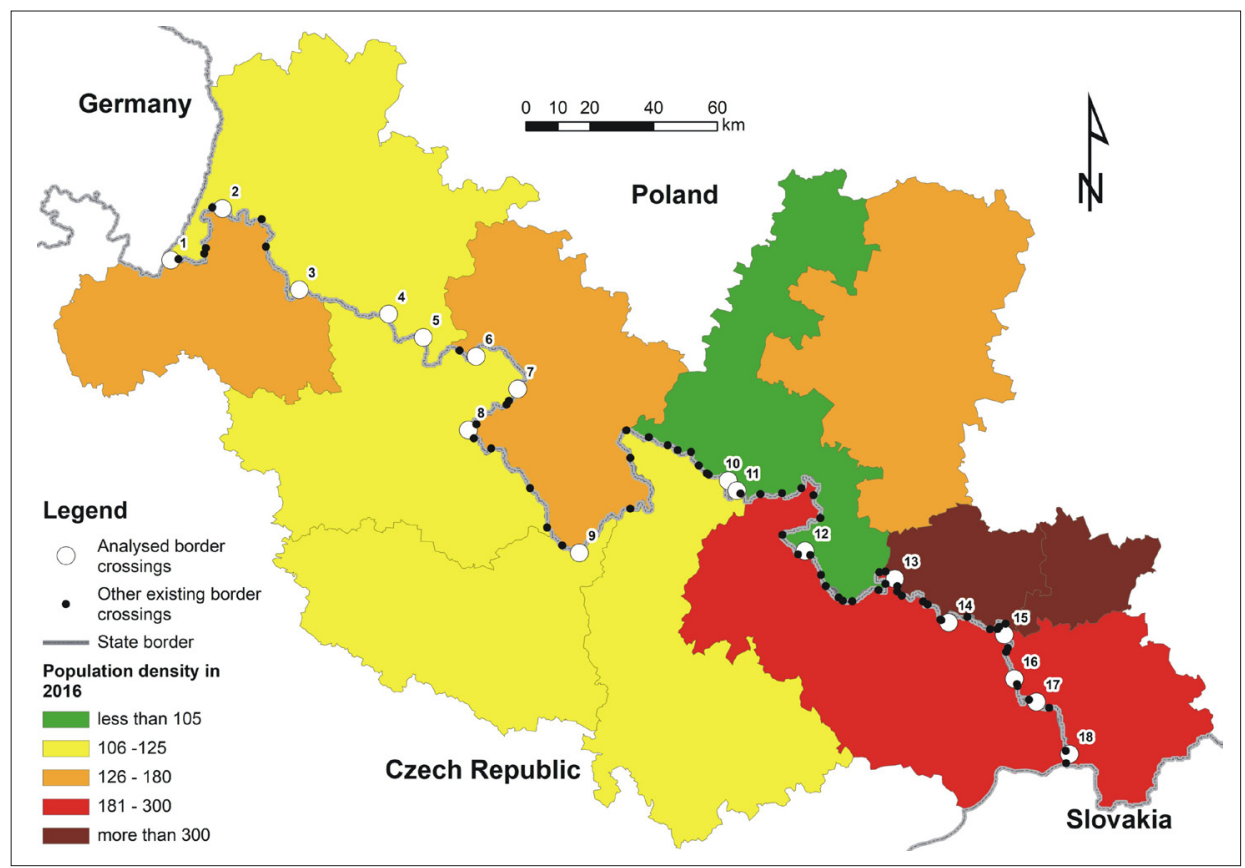

Fig. 1: The areas that were analysed, border crossing points as of 2016 and population density in border regions in 2016. Source: authors' elaboration

Note: Analysed border crossings: 1. Porajów (PL) - Hrádek nad Nisou (CZ); 2. Zawidów (PL) - Habartice (CZ); 3. Jakuszyce (PL) - Harrachov (CZ); 4. Przełęcz Okraj (PL) - Malá Úpa (CZ); 5. Lubawka (PL) - Královec (CZ); 6. Golińsk (PL) - Starostín (CZ); 7. Ttumaczów (PL) - Otovice (CZ); 8. Kudowa-Stone (PL) - Náchod-Běloves (CZ); 9. Boboszów (PL) - Dolní Lipka (CZ); 10. Gtuchołazy (PL) - Mikulovice (CZ); 11. Konradów (PL) - Zlaté Hory (CZ); 12. Pietrowice (PL) - Krnov (CZ); 13. Pietraszyn (PL) - Sudice (CZ); 14. Chałupki (PL) - Bohumín (CZ); 15. Marklowice (PL) - Petrovice u K. (CZ); 16. Cieszyn-Boguszowice $(P L)$ - Český Těšin-Chotěbuz (CZ); 17. Leszna Górna (PL) - Horní Líštná (CZ); 18. Jasnowice (PL) - Bukovec (CZ)

The analysis included only those facilities that were available to customers on site, excluding any private or state company headquarters. We also excluded ski-lift services that are available near four of the mountain border crossings included in the study, since these are not associated with typical border traffic and only operate seasonally.

The authors made use of the ArcGIS program for data visualisation. Spatial analyses were conducted using the NUTS 3 EU statistical unit areas (noted in Fig. 1), some of which extend as far as 25 kilometres away from the state border. The number of roads available for motor vehicles in 2016 was calculated using cartographic material: Ortofotomap, the Open Street Map database and Google street view, without taking into account local restrictions on vehicle tonnage.

\section{Background: The permeability of the Czech- Polish border from 1988 to 2016}

The Polish-Czech border is 796 kilometres in length (Statistics Poland, 2011), 80\% of which is located in the middle of mountainous areas. Regardless of the political context, orographic and natural determinants (for example, mountain ridges or river valleys that include a significant number of protected natural sites) have always played a significant role in limiting transport infrastructure development and border permeability for automobile traffic (Kolejka et al., 2015). Environmentally valuable areas, however, have also contributed to increased tourism development (Dołzbłasz, 2017; Furmankiewicz et al., 2019; Krajewski, 2019; Potocki et al., 2014; Przybyła and Kulczyk-Dynowska, 2017).

The borders in this part of Europe experienced significant changes after World War II. In 1945, the former border between Czechoslovakia and Germany, which covered a long section of the Sudetes, became the CzechoslovakianPolish border (Böhm and Šmída, 2019; Dołzbłasz, 2017; Eberhardt, 2017). There was almost no border permeability during the socialist period and, for a long time, the border was almost completely sealed off and protected on the Polish side by the Border Protection Forces, which existed until 1991. Various types of restrictions were applied to border areas during this period (the changes that took place between 1945 and 1988 are not the subject of this research: see Rychlík (2016), for example, for more detailed information). Using terminology established by Martinez (1994), it can be argued that the borderlands in question were 'alienated' or, periodically, 'coexistent.' Polish citizens could legally obtain a long-term passport that was valid worldwide since 1988 .

The fall of socialism and the onset of democratic elections in Czechoslovakia (in 1990) and Poland (in 1991) coincided with the signing of the Polish-Czechoslovak Agreement on visa-free travel in 1991. This agreement, which removed any requirement for persons to have special permits or visas to be able to cross the border, had a significant impact on crossborder travel. After the peaceful division of Czechoslovakia into the Czech and Slovak Republics in 1993, this agreement was maintained. In 1991, there were only 11 passport border crossing points available for automobile traffic on the PolishCzechoslovak border; by 1995, there were 19 passport crossings and 26 additional local border crossings without extensive infrastructure (intended for those who lived in these borderlands).

Throughout the 1990s, EU PHARE pre-accession support programs have proved to be of great significance for border areas, which had previously been underdeveloped due to their peripheral locations and to other legal restrictions, 
because these programs co-financed the construction and modernisation of roads and other local public infrastructure (Ciok, 2003).

In 1996, a new local border traffic agreement took effect. This agreement allowed residents of municipalities within 15 kilometres of the border to cross it using only their national identification cards, and to stay abroad for up to seven days. That same year, a number of passport border crossings that were part of tourist routes began to open up, offering access to pedestrians, as well as to some skiers and cyclists. By 2000, there were 22 road passport crossings, 30 local border traffic crossings and 20 small border crossings on mountain hiking and cycle tourist routes (most commonly in mountain regions). This period also represents an increase in the number of 'interdependent' borderland features according to the typology developed by Martinez (Komornicki, 1999; Stryjakiewicz, 1998).

In 2004, both countries joined the EU, resulting in the abolition of customs controls, leaving only passport checks. It also significantly increased the possibility of obtaining additional EU funding for the modernisation or construction of new infrastructure in peripheral border areas (Ciok and Raczyk, 2008; Dołzbłasz, 2013; Kachniarz et al., 2019; Rosik et al., 2015). In 2007, when Poland and the Czech Republic joined the Schengen area, passport controls were abolished and the control infrastructure at border crossing points was decommissioned (Directorate-General for Migration and Home Affairs, 2015). Borders ceased to be a barrier limiting the movement of people and vehicles, with the only exceptions being temporary controls that may be introduced in the case of epidemics, in order to ensure security for interstate summits, or for other special events (Kolosov and Więckowski, 2018).

Moreover, it was now legal to cross the border anywhere, with the exception of areas where pedestrian or automobile traffic was prohibited for other reasons, for example on designated routes within nature reserves or national parks. As a result of these formal facilitations and investments from local governments, the number of paved roads allowing border crossing increased significantly after 2007 . The total number of points where motorists could legally cross the Polish-Czech border increased from nine to 83 between 1991 and 2016 (see Tab. 2). Border permeability, measured by the number of crossing points per 100 kilometres of borderline, increased from about one in 1991 to two in 1995 and 10 in 2016. An increase in other kinds of cross-border connections was also observed, due largely to stronger cooperation between local communities and the public administration in functional areas that were divided by national borders (Dołzbłasz and Raczyk, 2010; Böhm and Drápela, 2017; Kurowska-Pysz and Szczepańska-Woszczyna, 2017; Potocki et al., 2014).

\begin{tabular}{ccccc}
\hline Year & $\mathbf{1 9 9 1}^{*}$ & $\mathbf{1 9 9 5}^{*}$ & $\mathbf{2 0 0 0}$ & $\mathbf{2 0 1 6}$ \\
\hline Number of border crossings & 9 & 19 & 22 & 83 \\
Border permeability rate & 1.13 & 2.38 & 2.76 & 10.42 \\
\hline
\end{tabular}

Tab. 2: Number of Polish-Czech border crossings and border permeability rate (measured in number of crossings per $100 \mathrm{~km}$, accessible for car)

Note: *The Okraj mountain pass - exclusively accessible to bicycles and pedestrians until 1998)

Sources: Compiled by the authors using data from the Polish Ministry of the Interior and Administration and from cartographic sources
The changes described above - which are both political (the conditions of crossing the border) as well as organisational (the number of border crossings or places offering passage across the border) - undoubtedly had a significant impact on Polish-Czech cross-border vehicle and pedestrian traffic. Unfortunately, there are no comparable data regarding cross-border traffic post-2007, when all controls had been abolished. Data from the primary international routes suggest, on the one hand, an increase in car traffic (Jurczek, 2002; Potocki et al., 2014) and, on the other, a dispersion, due to the introduction of a large number of new roads offering passage across the border (Kolejka et al., 2015). These changes have also had a strong influence on the development of service facilities located at former border crossings, although a detailed analysis of the PolishCzech border has not yet been conducted, at least in any English-language research findings. By investigating longterm changes at former formal border crossings, this article fills this gap in the literature.

\section{Results: Services in the vicinity of border crossings from 1995 to 2016}

The following section contains the results of field studies conducted at 18 border crossings in the years 1995, 2000 and 2016. The tables and figures show only aggregated data. Between 1995 and 2000, the increase in cross-border traffic and the fact that border crossings retained their control functions, led to a spike in the number of trading facilities on both sides of the border (see Fig. 2). At the same time, there was a slight decrease in the number of small gastronomic establishments on the Polish side of the border and an increase on the Czech side (Fig. 3); while the number of facilities providing other types of services showed a slight increase (Fig. 4).

The highest growth levels observed during the 1995-2000 period involved trade, gastronomy and other services offered at border crossings located in towns adjacent to the border, suggesting that it was not transit traffic, but local shopping traffic that played the most significant role in services development. During that period, it was convenient for Poles to purchase alcohol and some food at lower prices in the Czech Republic, and for Czechs to acquire certain industrial goods, such as furniture or bedding, in Poland. The specific customs limitations (which limited the amount of goods that could be transported per capita during a single cross-border visit), coupled with there being no limitation on the number of times one could cross the border, led to a rise in small-scale smuggling, mostly with regard to alcohol (because people crossed the border multiple times with smaller amounts of goods that did not exceed the legal limit). The relatively high cost of compulsory international car insurance also encouraged Poles to leave their vehicles at a border crossing parking lot, and to walk to the Czech side of the border to do their shopping. This led to a significant growth in small grocery stores on the Czech side.

The occasional customers, as well as the small-scale smugglers who spent a relatively longer amount of time near the border crossing, had a stimulating effect on the development of small, non-durable gastronomy establishments (in particular for Polish shoppers on the Czech side of the border), and currency exchange booths (in particular for Polish shoppers and alcohol smugglers buying Czech currency). This was especially true at the Marklowice/Petrowice, Chałupki/Bohumín and Zawidów/ Habartice crossings and at the urban crossing in Cieszyn/ 
Český Těšín (which, in reality, was comprised of two bridges allowing one-way traffic). Another factor which impacted the development of borderland services was transit traffic, for example, when a border crossing was part of an international or state road. This was the case of the Chałupki/Bohumin and Kudowa Słone/Náchod Běloves crossings. Services provided at crossings that were located further from the nearest town were much less developed, even if they were part of transit roads (e.g. Jakuszyce/Harrachov, Międzylesie/Lichkov). Most often, they comprised a small number of non-durable kiosks that were easy to relocate; examples include Porajów/Hrádek n. Nisou, Jakuszyce/Harrachov, Boboszów/Dolní Lipka, Głuchołazy/Mikulovice, Konradów/Zlaté Hory, Pietrowice/ Krnov, Pietraszyn/Sudice and Górna Liszna/Horní Líštná.

The Czech side of the border generally offered more outlets providing a greater variety of services. Transporting large-size industrial goods - something of great interest to Czech customers - required the use of automobiles and large-area stores, so Czechs usually preferred to visit towns closest to the Polish side of the border, leading to much poorer development of trade outlets near these border crossings. Other services were of less importance, but they were usually better developed on the Polish side: these included insurance branches and freight business offices. Such services would most commonly prosper at crossings located in borderland towns.

Between 2000 and 2016 the number of retail centres dropped to levels below those of 1995 on both sides of the border. This was mostly a result of a decline in grocery stores, primarily due to a gradual decrease in the affordability of transporting alcohol to Poland and the wide availability of tax-free wholesale shopping (because the ease of cargo transport led to the complete eradication of small-scale smuggling). The largest decrease in the number of retail points was observed on both sides of the Zawidów/Habartice and Chałupki/Bohumín crossings, and mainly on the Czech side of the Lubawka/Královec, Golińsk/Starostín and Kudowa Słone/Náchod Běloves crossings.

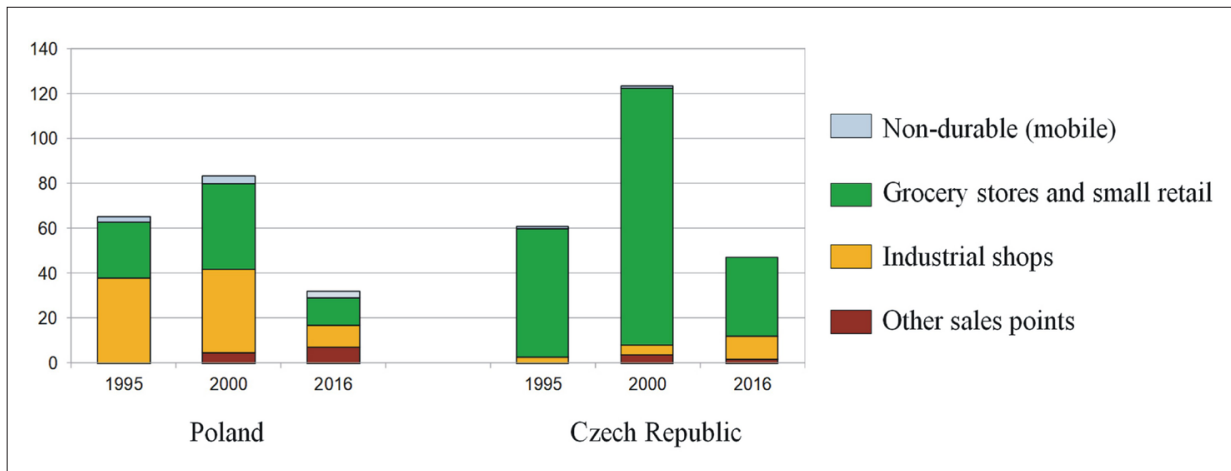

Fig. 2: Number of commercial outlets at Czech-Polish border crossings (excluding the Cieszyn/Český Těšín centre) Source: authors' field research

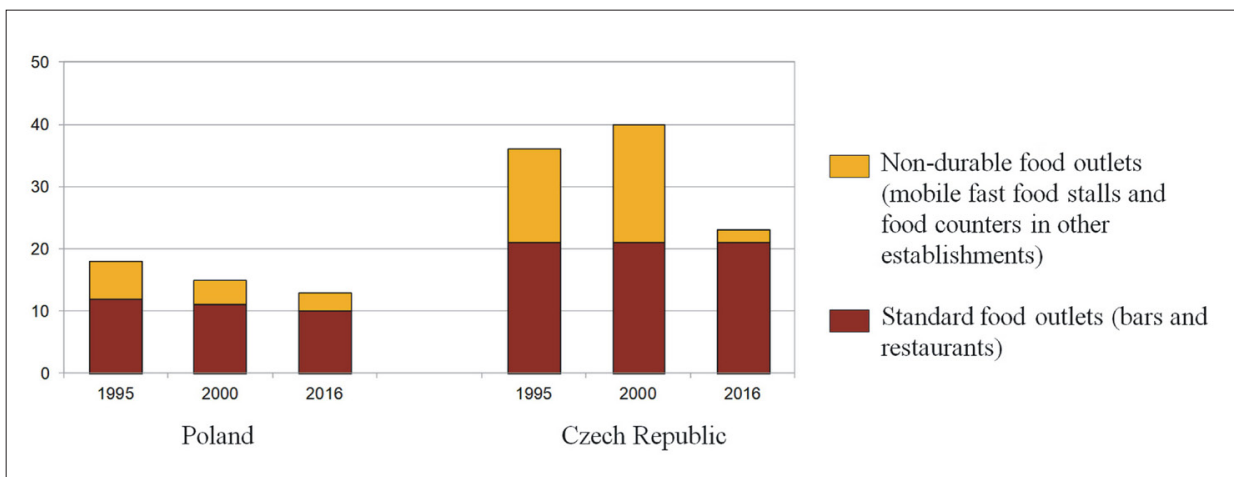

Fig. 3: Number of gastronomic facilities at Czech-Polish border crossings (excluding the Cieszyn/Český Těšín centre) Source: authors' field research

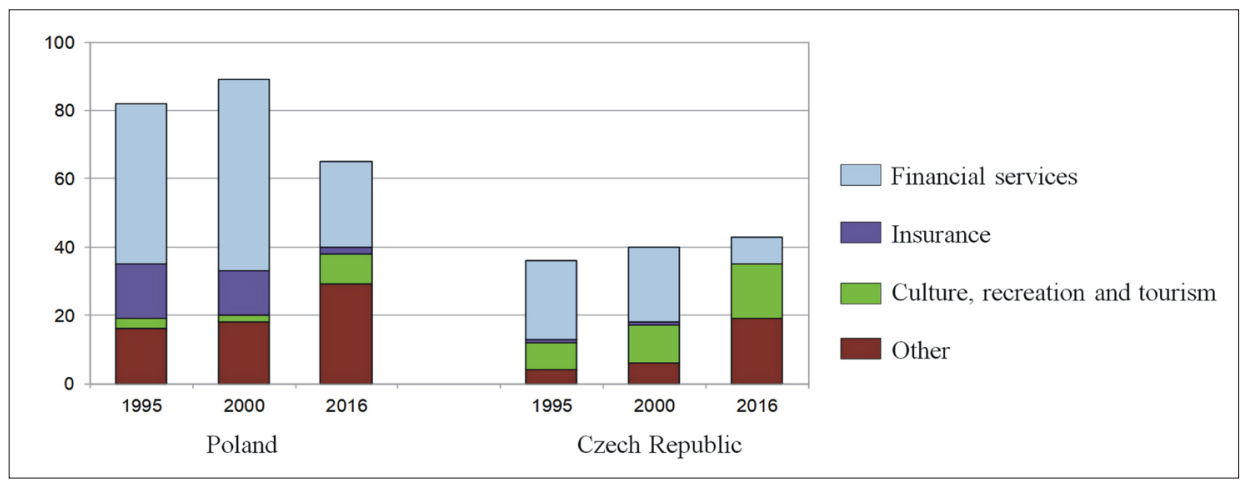

Fig. 4: Number of other service establishments at Czech-Polish border crossings (excluding the Cieszyn/Český Těšín centre). Source: authors' field research 
Between 2000 and 2016, there was also a decline in small, usually non-durable, fast-food outlets in the areas we studied, with practically no such decrease noted for higherlevel gastronomic establishments.

There was an increase in facilities on the Czech side of the Zawidów/Habartice and Okraj pass/Malá Úpa crossings in the Sudetes, which may be the result of increased tourist traffic. The number of currency exchange booths and insurance companies has also decreased. Customs-related services have also dwindled (given the fact that fewer documents need to be filled out), with only a few still remaining at border crossings with the highest cargo traffic. The most diverse array of service outlets was at crossings located near towns and large villages (e.g. Zawidów/Habartice, Kudowa Słone/Náchod Běloves, Chałupki/Bohumin). One interesting case is that of the Kudowa Słone/Náchod Běloves crossing, which is located on the international E67 road. This crossing experienced almost all of the changes described here: a decrease in the number of small trade, gastronomic and financial outlets, along with the establishment of a largearea store on the Czech side (see Fig. 5).

Most other types of services were those that had no direct relation to the border crossings themselves, rather they encompassed services for the local inhabitants of borderland

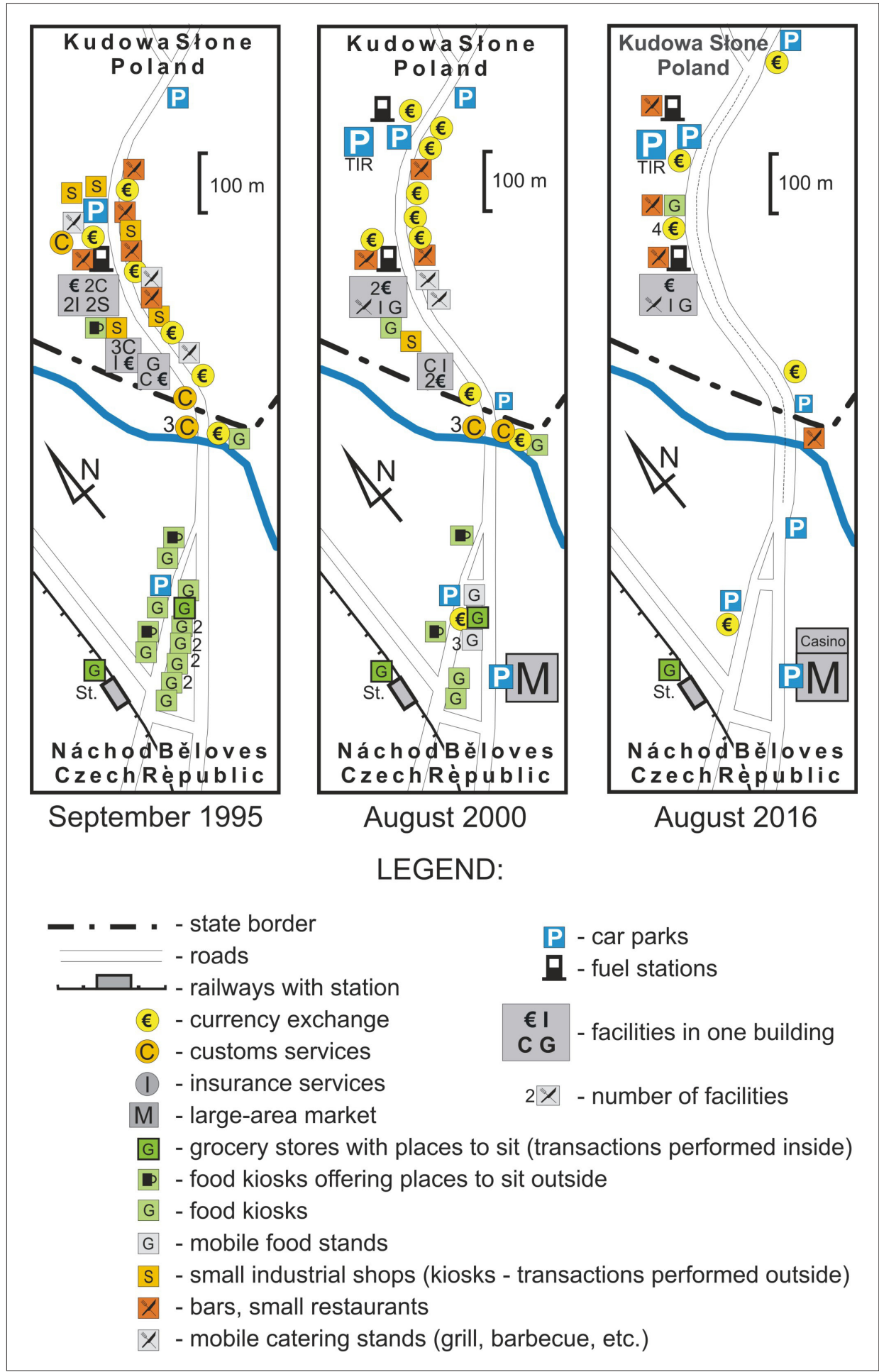

Fig. 5: Service establishments at the Náchod Běloves/Kudowa Stone border crossing in 1995, 2000 and 2016 (schematic plan). Source: compiled by the authors from Furmankiewicz (2000) and Buryto (2017) 
towns, such as post office branches, banks, schools and preschool institutions, craftsmen and local associations. In this category, the number of non-financial and non-insurance services at the border crossings under review has also increased, with a rise in the number of service facilities related to culture, recreation and tourism on both the Czech and Polish sides.

We do not have fully comparable data on border crossings in the centre of Cieszyn/Český Těšín. Available data relate to the total number of outlets within 500 metres of either border bridge. These data suggest that, between 1995 and 2016, the number of permanent catering establishments (bars and restaurants) increased on both sides of the border (in Poland from about 17 to 45, in Czech Republic from about 21 to 26). At the same time, there was a significant decrease in the number of small, non-durable (including mobile) outlets. The number of retail outlets has dropped significantly on both sides of the border, primarily due to the decrease in small industrial stores, which was more significant on the Polish side of the border (while at crossings described earlier, the decrease was also important, but it was seen among grocery stores as opposed to industrial stores, since the latter were not present at those crossings). Asymmetric changes also took place with regard to financial institutions: Poland saw a decrease from around 23 to two, while Czech Republic saw an increase from around six to eight. Insurance services had negligible significance, with only one branch on the Czech side in 2016. On the other hand, as with the other border crossings we analysed, the number of service facilities related to recreation, sport and tourism increased both in Poland (from about three to 12) and Czech Republic (from about four to seven).

Our results suggest a clear diversification in terms of economic activity in the vicinity of border crossings by 2016 . The authors have therefore established a simple typology of border crossings with regard to the three categories of services that were analysed: retail, gastronomy and other service functions (see Tab. 3). The 'commercial function' applies when a total of two or more retail outlets were located on both sides of a former crossing. The 'gastronomy function' applies when there were more than two outlets in this category and the 'other service function' applies when there were more than four outlets of this kind. Border crossings that had no assigned function were named 'corridors' (type C), because their main purpose was to enable transport to a neighbouring country. Those with one or two functions were designated as areas with low levels of service development (type L). Finally, those with all three functions were identified as multifunctional areas servicing travellers (type $\mathrm{M}$ ).

In 2016, based on this typology, 10 of the border crossings under evaluation served exclusively as transport corridors, offering no significant service functions (type C). The majority of these were located in mountain regions (seven in the Sudetes and two in the Beskids), with only one being located in the Silesian Lowlands (see Fig. 6). Almost all crossings of this type were located at a distance from borderland towns, with two of them being part of international roads. A low level of development in service functions (type L) was observed at three crossings: two were characterised by structures that made them part of local villages that abutted the state border; and one was a travellers' service station on an express road (Cieszyn-Boguszowice/Český Těšín-Chotěbuz). Five crossings were assigned the multifunctional (type $\mathrm{M}$ ) category: four were located in small towns adjacent to the border (on both the Polish and Czech sides); one - the Okraj pass/Malá Úpa - was connected to the mountain tourist village of Malá Úpa in the Krkonoše/Karkonosze Mountains. The two border crossings in Cieszyn/Český Těšín centre were characterised by the highest number and diversity of service establishments and were thus classified as "type M."

\begin{tabular}{|c|c|c|c|c|c|}
\hline No & Analysed border crossing area & $\begin{array}{l}\text { Commercial } \\
\text { functions }\end{array}$ & $\begin{array}{l}\text { Gastronomic } \\
\text { functions }\end{array}$ & $\begin{array}{l}\text { Other service } \\
\text { functions }\end{array}$ & Type \\
\hline 1 & Porajów (PL) - Hrádek nad Nisou (CZ) & YES & YES & YES & M \\
\hline 2 & Zawidów (PL) - Habartice (CZ) & YES & YES & YES & $\mathrm{M}$ \\
\hline 3 & Jakuszyce (PL) - Harrachov (CZ) & NO & NO & NO & $\mathrm{C}$ \\
\hline 4 & Przełęcz Okraj (PL) - Malá Úpa (CZ) & YES & YES & YES & M \\
\hline 5 & Lubawka (PL) - Královec (CZ) & NO & NO & NO & $\mathrm{C}$ \\
\hline 6 & Golińsk (PL) - Starostín (CZ) & YES & YES & NO & $\mathrm{L}$ \\
\hline 7 & Tłumaczów (PL) - Otovice (CZ) & NO & NO & NO & $\mathrm{C}$ \\
\hline 8 & Kudowa-Słone (PL) - Náchod-Běloves (CZ) & YES & YES & YES & M \\
\hline 9 & Boboszów (PL) - Dolní Lipka (CZ) & NO & NO & NO & $\mathrm{C}$ \\
\hline 10 & Głuchołazy (PL) - Mikulovice (CZ) & NO & NO & NO & $\mathrm{C}$ \\
\hline 11 & Konradów (PL) - Zlaté Hory (CZ) & NO & NO & NO & $\mathrm{C}$ \\
\hline 12 & Pietrowice (PL) - Krnov (CZ) & NO & NO & NO & $\mathrm{C}$ \\
\hline 13 & Pietraszyn (PL) - Sudice (CZ) & NO & NO & NO & $\mathrm{C}$ \\
\hline 14 & Chałupki (PL) - Bohumín (CZ) & YES & YES & YES & M \\
\hline 15 & Marklowice (PL) - Petrovice u K. (CZ) & YES & NO & NO & $\mathrm{L}$ \\
\hline 16 & Cieszyn-Boguszowice (PL) - Č. T. - Chotěbuz (CZ) & YES & NO & YES & $\mathrm{L}$ \\
\hline 17 & Leszna Górna (PL) - Horní Líštná (CZ) & NO & NO & NO & $\mathrm{C}$ \\
\hline 18 & Jasnowice (PL) - Bukovec (CZ) & NO & NO & NO & $\mathrm{C}$ \\
\hline
\end{tabular}

Tab. 3: Proposed typology for the former border crossings under evaluation, with regard to current (2016) development of retail and service establishments Source: authors' field research 


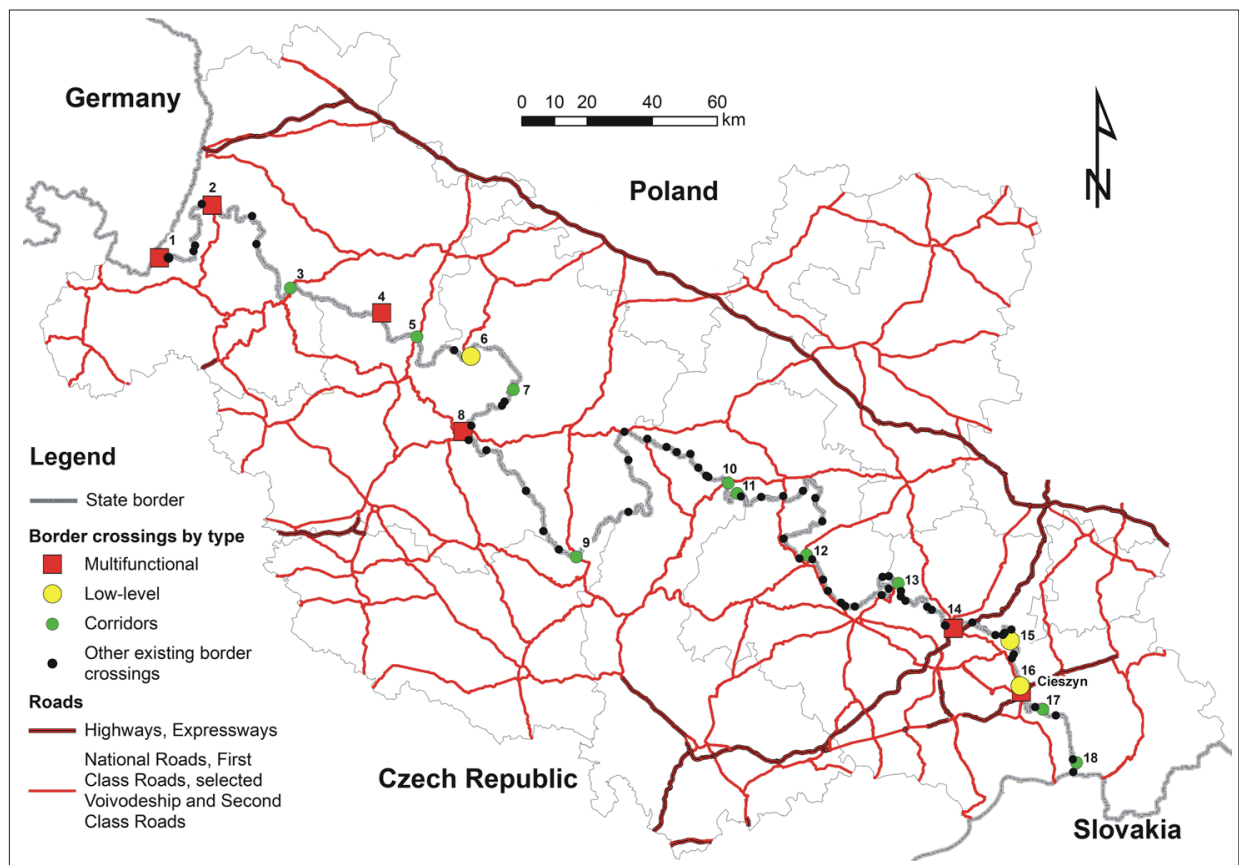

Fig. 6: The current typology of analysed border-crossing points (2016). Source: authors' field research

Note: Analysed border crossing points: 1. Porajów (PL) - Hrádek nad Nisou (CZ); 2. Zawidów (PL) - Habartice (CZ); 3. Jakuszyce (PL) - Harrachov (CZ); 4. Przełęcz Okraj (PL) - Malá Úpa (CZ); 5. Lubawka (PL) - Královec (CZ); 6. Golińsk (PL) - Starostín (CZ); 7. Ttumaczów (PL) - Otovice (CZ); 8. Kudowa-Stone (PL) - Náchod-Běloves (CZ); 9. Boboszów (PL) - Dolní Lipka (CZ); 10. Gtuchołazy (PL) - Mikulovice (CZ); 11. Konradów (PL) - Zlaté Hory (CZ); 12. Pietrowice (PL) - Krnov (CZ); 13. Pietraszyn $(P L)$ - Sudice (CZ); 14. Chatupki (PL) - Bohumin (CZ); 15. Marklowice (PL) - Petrovice u K. (CZ); 16. Cieszyn-Boguszowice (PL) - Český Těšin-Chotěbuz (CZ); 17. Leszna Górna (PL) - Horní Líštná (CZ); 18. Jasnowice (PL) - Bukovec (CZ).

\section{Discussion}

Our analysis shows that, between 1995 and 2016, there was a decrease in the total number of service outlets in the vicinity of all Czech-Polish border crossings, whether in rural or urban areas. The reasons for these changes, however, are diverse and depend on a number of local determinants. Table 4 summarises our evaluation of the impact of certain factors on the growth or decline of certain types of service outlets at these border crossings.

The abolition of customs and passport controls removed the need to stop at the border. It also eliminated smallscale smuggling, which had stimulated the development of certain services prior to 2004. This was especially true for a number of small retail outlets that had benefitted from both smuggling and from shoppers seeking out better prices for goods on the other side of their own state border (Tab. 5). Price differences are a common factor in the stimulation of cross-border shopping (Cosaert, 1994; Fullerton and Walke, 2019; Powęska, 2008).

Due to a lack of control and price equalisation, border shopping intensity has decreased significantly and small shops that previously thrived at border crossings have closed. Both countries have also experienced a decline in the number of small grocery stores and convenience stores, as a result of

\begin{tabular}{|c|c|c|c|c|c|}
\hline \multirow{2}{*}{ Factor affecting the development of services } & \multicolumn{5}{|c|}{ Type of services } \\
\hline & Retail & Gastronomy & Finance & Insurance & $\begin{array}{l}\text { Culture, recreation, } \\
\text { tourism }\end{array}$ \\
\hline $\begin{array}{l}\text { Traffic de-concentration resulting from the introduction } \\
\text { of new border crossings }\end{array}$ & - & - & - & - & - \\
\hline $\begin{array}{l}\text { Traffic increases resulting from the abolition of border } \\
\text { controls }\end{array}$ & + & + & + & + & + \\
\hline Elimination of customs barriers & + & 0 & 0 & 0 & 0 \\
\hline Levelling of the prices of goods as a result of integration & - & 0 & - & 0 & 0 \\
\hline Electronic banking & + & 0 & - & - & + \\
\hline Compulsory insurance valid across Europe & 0 & 0 & 0 & - & + \\
\hline $\begin{array}{l}\text { Introduction of large-area store networks, resulting in } \\
\text { decreases in small retail outlets }\end{array}$ & - & 0 & 0 & 0 & 0 \\
\hline $\begin{array}{l}\text { Total result (growth/low influence/decline for given } \\
\text { type of outlet in the border area) }\end{array}$ & decline & low influence & decline & decline & growth \\
\hline
\end{tabular}

Tab. 4: Evaluation summary of the impact of certain factors on the growth (+), decline (-) or stagnation (0) of certain types of service outlets located in the vicinity of border crossings. Source: authors' field research 


\begin{tabular}{lcrr}
\hline \multirow{2}{*}{ Category or country } & & \multicolumn{3}{c}{ Year } \\
\cline { 3 - 4 } & & 2000 & 2016 \\
\hline Alcoholic beverages & $\mathrm{CZ}$ & 60,2 & 84,7 \\
& $\mathrm{PL}$ & 107,3 & 83,4 \\
Furniture and furnishings, carpets and other floor coverings & CZ & 74,4 & 71,7 \\
& PL & 68,4 & 72,5 \\
Restaurants and hotels & Difference & 6,0 & $-0,8$ \\
& CZ & 48,0 & 56,2 \\
& PL & 70,1 & 70,8 \\
& Difference & $-22,1$ & $-14,6$ \\
\hline
\end{tabular}

Tab. 5: Price level indices (EU27, $2007=100)$ in Poland and the Czech Republic from 2010 to 2016 for select product categories (no data before 1999; acronyms: CZ - the Czech Republic; PL - Poland)

Source: Compiled by authors using data available from Eurostat (2020)

the development of large-area store networks and discount stores (Machek, 2012; Twardzik and Heffner, 2019). This may be another reason for the decline in the number of small industrial stores in Cieszyn/Český Těšín. Another important factor may be income growth among Poles and Czechs as a result of recent economic transformation (Fałkowski et al., 2014). This has led, among other factors, to an increase in the number of registered cars in both countries (Kilsilowski and Zalewski, 2010), which has facilitated private transport to nearby border towns that offer a greater diversity and higher standard of services. Income growth has also had a positive impact on tourism development (Więckowski, 2010).

The number of insurance branches and financial outlets (primarily currency exchange booths) has also decreased significantly. The decline in the availability of these services can be attributed to the fact that citizens of these two countries no longer need to purchase so-called 'green cards' (international automobile insurance) or extra health insurance when travelling abroad, thanks to the introduction of the European Health Insurance Card. In spite of maintaining national currencies in Poland and the Czech Republic, the growing availability of electronic bank services, such as cashpoints and the ability to pay via debit or credit cards (Ilnicki, 2009), has reduced demand for currency exchanges.

Interestingly, the number of durable gastronomic facilities has generally remained unchanged, with a notable development in such services in the Polish part of Cieszyn/ Český Těšín, which offers a historic market square and is a focal point for local tourism and services (Böhm and Drápela, 2017; Dołzbłasz, 2015; Kulczyńska and Matykowski, 2008). The development of tourism - and cross-border tourism in particular - has contributed significantly to maintaining the demand for catering services (Dołzbłasz, 2015, 2017). This is a typical phenomenon in many border areas, especially those located in regions with landscapes and historical sites that attract tourists (Więckowski, 2010; Pawlusiński and Kubal, 2015; Prokkola, 2010).

Another contributing factor to asymmetry in the development of certain establishments on both sides of the border is the difference in infrastructure development and settlement structures in the Polish and Czech parts of the Sudetes. The forced expulsion of Germans between 1945 and 1950, the strict military protection of border areas during the Communist era, and restrictions on borderlands and their peripheral economic locations in the Sudetes, have resulted in the depopulation and de-capitalisation of some areas. This includes the disappearance of villages, especially on the Polish side of the border (Ciok, 1990; Heffner, 1998; Hełdak and Kempa, 2007; Latocha, 2012; Oleszek, 2007; Szmytkie and Tomczak, 2017). As a result, there has been less intensive development of local infrastructure in the Polish Sudetes, which in turn has limited the establishment of service facilities near mountain border crossings. In the relatively densely populated lowlands of the Silesia-Moravia region (the central-eastern part of the Polish-Czech border), where forced migration processes were less intense, services - however different in structure - more frequently developed on both sides of the border.

The results of the research suggest, primarily, that border shopping is moving away from border crossings to the towns nearest to those crossings. It is also seeing gradual declines as a result of more equitable prices on both sides of the border. In addition, since there is no longer a requirement to stop at the border, there has been a decrease in the number of service facilities dedicated to travellers, while greater levels of accessibility have meant that nearby towns now offer a wider array of services due to existing local demand.

It is probable that borderland tourists, as well as local residents, also make use of the more recently introduced crossings (which were not investigated here) that are more relevant to local movement. Although there has been an increase in cross-border traffic on international routes (Jurczek, 2002; Komornicki, 1999; Potocki et al., 2014), this research indicates that transit traffic has limited impact on services development at border crossing points (for example, certain international roads located outside of urban areas have no services at all). Local traffic is generally of much greater significance in the development of service outlets and may lead to the establishment of new businesses at these new crossing points; however, it can be assumed that this has not happened in part because of the factors described above (the lack of border controls, the shift in demand to nearby cities, price equalisation and the development of electronic payment options). Further studies will be needed to confirm these assumptions.

The majority of former border crossings located outside of towns have become nothing more than transport corridors, offering no significant services. Their growth history has a characteristic pattern (Fig. 7). During the Communist 
A

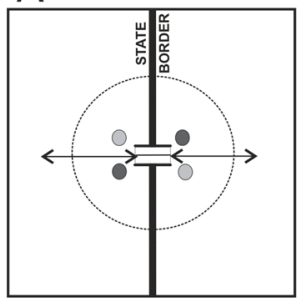

B

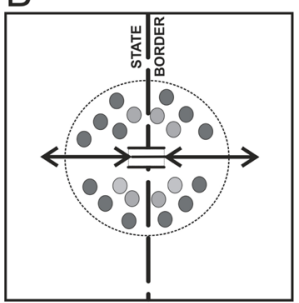

C

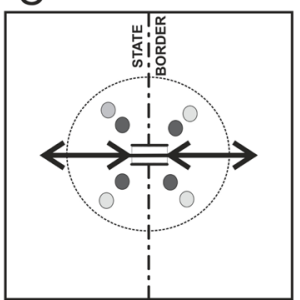

D

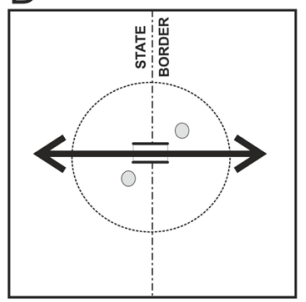

Fig. 7: Evolution of the general patterns of border crossings located outside urban areas. After the border opened, crossings usually function exclusively as transport channels, offering no significant services. See the text for further explanation. Source: based on authors' field research

era, although there was a small number of border crossings, travel was limited. This meant that very few service facilities were developed at border crossings (Stage A). As freedom of movement increased - obtaining a passport was easier, there were no requirements for visas and there was an increase in trade contacts - these crossings, which still maintained border controls, saw their maximum levels of growth in terms of service outlets (Stage B). Removing customs barriers while maintaining passport control resulted in a slight decrease in the number of service outlets (Stage C). Finally, eliminating all border controls and removing the need to stop at the border crossing led to the most significant decrease in services offered there (Stage D). This is similar to several models proposed by other authors (e.g. Ciok, 1990, p. 14; Martinez, 1994, p. 7), but our focus is on services development at border crossings that are not within cities or villages.

In this context, the so-called 'tunnel effect,' observed at former transit border crossings such as Jakuszyce/Harrachov and Cieszyn-Boguszowice/Český Těšín-Chotěbuz, is also relevant. High intensity cross-border transport passages on highways and express routes that have no border control allow for a practically seamless border crossing. One such example is the A-1 Highway, which was created after the countries entered the Schengen area; this crossing point has no travellers' service station at the Polish-Czech border and no border control infrastructure.

It would be beneficial to compare the results of this study with data related to borders in Europe, but the authors are unaware of any other publicly available multiyear comparisons of changes in the structure and number of service outlets located in the vicinity of former border crossings. The findings here undoubtedly mirror the experiences of those in Western and Northern European states (Prokkola, 2010; Szytniewski et al., 2017), which began eliminating border controls much earlier than postsocialist countries (the Schengen area was created in 1985). Similar asymmetric changes at crossing points have been observed on the Franco-Belgian border by Cosaert (1994); other research shows that, in cases of borders being opened, shopping tends to concentrate in neighbouring towns and villages (Szytniewski et al., 2017; Dołzbłasz and Zelek, 2019), while former border crossings serve mainly as transit routes (Prokkola, 2010).

The Polish-Czech border transformations detailed in this study have also been reinforced by changes in the pull/push and keep/repel factors. Some pull factors have declined - the high differences in prices, for example - as have certain push factors, such as greater accessibility of goods from the neighbouring state in one's own country. The role of recreational tourism, on the other hand, has certainly increased (Dołzbłasz, 2017; Więckowski, 2010), a finding which is common in the borderlands of other countries undergoing integration processes (Kolosov and Więckowski, 2018; Prokkola, 2010).

\section{Conclusions}

In large part, the results of this study confirm that the diminishing role of the border as barrier may lead to a reduction in the intensity of certain cross-border interactions. Between 1995 and 2016, there was a sharp decrease in the intensity of shopping at the Polish-Czech border crossings. This is also a question of symmetrical and asymmetrical relations in borderland areas. Our study confirms that increased price equity (e.g. with regard to consumer commodities), introducing universal principles as a result of changes in neighbouring countries (such as customs or European insurance) and general trends (such as the increased availability of electronic payment) lead to increased symmetry on both sides of the border. This may in turn lead to a decrease in cross-border interactions. It should be pointed out that a decrease in relations within a given domain may be accompanied by an increase in another. In the areas we studied, this certainly applies to the development of cross-border tourism and, to a lesser extent, to commuters travelling to or from work (primarily Poles commuting to the Czech Republic).

When analysing the above changes, the authors did not work from the assumption that opening the border was the only factor influencing the type and number of service outlets at former border crossings. The above-mentioned processes related to European integration also affected the types of services in both countries. In order to unambiguously evaluate the impact of the border on local service structure, it would be necessary to compare the changes observed within each country to the changes seen in the borderland areas. This would require additional in-depth studies, as well a broader regional evaluation.

The changes observed in relation to the manner in which former border crossings function seem to indicate that, in the case of significant integration processes, it is only those crossings located within settlement units (in other words, borderland towns) that are able to transform into multifunctional service areas. Crossings outside settlement areas are most often transformed into little more than transport corridors. This suggests that local and tourist traffic has a greater impact on these transformations than transit traffic. Therefore, after a border ceases to be a barrier, the rationale for where services are located is probably closer to that of classical retail location theories, in which settlement centres of various rank are of greatest importance (Borchert, 1998). 
It is evident that towns and cities most often serve as 'generators' for various types of cross-border connections (in fields such as cooperation, trade and tourism). Being located in an area that attracts tourism, which in turn generates cross-border mobility and fosters demand for services, is another element that may be one of the deciding factors in whether a border area maintains or further develops its services (Dołzbłasz, 2017). These processes could be considered indicative of the process of European integration (Prokkola, 2010), since it seems that the tendencies observed in former Polish-Czech border crossings are, to a large degree, universal in character, particularly when viewed against the backdrop of the European de-bordering processes that are a result of the EU's governing principles and the creation of the Schengen area. In brief, there is evidence of scalar mechanisms at work here.

The results of our analyses confirm that, as border regions become more integrated, the role of the border as a stimulator of local socioeconomic change decreases. Border areas gradually acquire the features of internal areas. For those working in spatial and economic planning, it is therefore worth applying methods more typical for the support and development of settlement centres, which are natural service centres. On the other hand, cultural and ethnic differences may still stimulate the development of tourism, which is highly important on the Polish-Czech border, given the physical and geographical characteristics of the region, as a significant part of the border is in mountain regions or includes natural and historic attractions. For local governments, it is therefore worth paying special attention to the promotion and creation of infrastructure taking into account tourism from neighbouring countries.

\section{Acknowledgement}

The paper was prepared as part of project 2018/31/B/ HS4/00550 "Stability of transborder cooperation on the example of Polish borderlands," financed by the National Science Centre, Warsaw, Poland.

\section{References:}

ACKLESON, J. (2005): Constructing Security on the U.S.Mexico border. Political Geography, 24(2): 165-184.

AGNEW, J. (2008): Borders on the mind: reframing border thinking. Ethics and Global Politics, 1(4): 175-191.

ANDERSON, J., O'DOWD, L. (1999): Borders, Border Regions and Territoriality: Contradictory Meanings, Changing Significance. Regional Studies, 33(7): 593-604.

ANISIEWICZ, R., PALMOWSKI, T. (2014): Small border traffic and cross-border tourism between Poland and the Kaliningrad Oblast of the Russian Federation. Quaestiones Geographicae, 33(2): 79-85.

BLATTER, J. K. (2001): Debordering the World of States: Towards a Multi-Level System in Europe and a MultiPolity System in North America? Insights from Border Regions. European Journal of International Relations, 7(2): 175-209.

BÖHM, H., DRÁPELA, E. (2017): Cross-border cooperation as a reconciliation tool: Example from the East Czech-Polish borders. Regional \& Federal Studies, 27(3): 305-319.

BÖHM, H., OPIOŁA, W. (2019): Czech-Polish Cross-Border (Non) Cooperation in the Field of the Labor Market:
Why Does It Seem to Be Un-De-Bordered? Sustainability, 11(2855): 1-13.

BÖHM, H., ŠMÍDA, J. (2019): Borders on the old maps of Jizera Mountain. Miscellanea Geographica - Regional Studies on Development, 23(4): 199-209.

BOONCHAI, P., FREATHY, P. (2020): Cross-border tourism and the regional economy: a typology of the ignored shopper. Current Issues in Tourism, 23(5): 626-640.

BORCHERT, J. G. (1998): Spatial dynamics of retail structure and the venerable retail hierarchy. GeoJournal 45(4): 327-336.

BURYŁO, K. (2017): Analiza rozwoju polsko-czeskich obszarów przygranicznych. Master's Thesis. Wrocław, Wroclaw University of Environmental and Life Sciences, Department of Spatial Economy.

BYGVRÃ, S., WESTLUND, H. (2004): Shopping Behaviour in the Øresund Region Before and After the Establishment of the Fixed Link between Denmark and Sweden. GeoJournal, 61(1): 41-52.

CAPELLO, R., CARAGLIU, A., FRATESI, U. (2018): Measuring border effects in European cross-border regions. Regional Studies, 52(7): 986-996.

CIOK, S. (1990): Problematyka obszarów przygranicznych polski południowo-zachodniej. Studium społecznoekonomiczne. Acta Universitatis Wratislaviensis No 1155. Wrocław, Państwowe Wydawnictwo Naukowe.

CIOK, S. (2003): The Financing of International, Crossborder Co-operation between Central- and EastEuropean Countries by the European Union. In: Kitowski, J. [ed.]: Eastern dimension of European Union (pp. 405-413). Warsaw, Polish Academy of Sciences, Institute of Geography and Spatial Organization.

CIOK, S., RACZYK, A. (2008): Implementation of the EU Community Initiative INTERREG III $\mathrm{A}$ at the Polish-German border: An attempt at evaluation. In: Leibenath, M., Korcelli-Olejniczak, E., Knippschild, R. [eds.]: Cross-border governance and sustainable spatial development: mind the gaps (pp. 33-47). Berlin, Springer Verlag.

COSAERT, P. (1994): Frontière et commerce de détail: la localisation des commerces de détail aux points de passage de la frontière franco-belge au niveau de l'arrondissement de Lille. Hommes et Terres du Nord, 2-3: 134-141.

DAVIS, D. F., FRISKE, W. (2013): Defining the Soft Infrastructure of Border Crossings: A Case Study at the Canada-US Border. American Review of Canadian Studies, 43(4): 477-493.

DIRECTORATE-GENERAL FOR MIGRATION AND HOME AFFAIRS (2015): Europe without borders. The Schengen area. Bruxelles, European Commission.

DOŁZBŁASZ, S. (2013): Cross-Border Co-Operation in the Euroregions at the Polish-Czech and Polish-Slovak Borders. European Countryside, 5(2): 102-114.

DOŁZBŁASZ, S. (2015): Symmetry or asymmetry? Crossborder openness of service providers in Polish-Czech and Polish-German border towns. Moravian Geographical Reports, 23(1): 2-12.

DOŁZBŁASZ, S. (2017): From Divided to Shared Spaces: Transborder Tourism in the Polish-Czech Borderlands. In: Hall, D. [ed.]: Tourism and geopolitics: issues and 
concepts from Central and Eastern Europe (pp. 163177). Wallingford, Boston, CABI.

DOŁZBŁASZ, S., RACZYK, A. (2010): The Role of the Integrating Factor in the Shaping of Transborder Co-Operation: The Case of Poland. Quaestiones Geographicae, 29(4): 65-73.

DOŁZBŁASZ, S., RACZYK, A. (2017): Transborder cooperation and competition among firms in the PolishGerman borderlands. Tijdschrift voor Economische en Sociale Geografie, 108(2): 141-156.

DOŁZBŁASZ, S., ZELEK, K. (2019): Wybrane cechy zagospodarowania przestrzennego i aktywności gospodarczej w otoczeniu miejsc przekraczania granicy polsko-niemieckiej. Przegląd Geograficzny, 91(4): 487-510.

EBERHARDT, P. (2017): Political and administrative boundaries of the German state in the 20th century. Geographia Polonica, 90(3): 335-350.

FAŁKOWSKI, J., JAKUBOWSKI, M., STRAWIŃSKI, P. (2014): Returns from income strategies in rural Poland. Economics of Transition, 22(1): 139-178.

FULLERTON Jr., T. M., WALKE, A. G. (2019): Cross-Border Shopping and Employment Patterns in the Southwestern United States. Journal of International Commerce, Economics and Policy, 10(3): 1-19.

FURMANKIEWICZ, M. (1996): Zagospodarowanie przestrzenne polsko-czeskich obszarów przygranicznych. Master's Thesis. Wrocław, Institute of Geography, Wrocław University.

FURMANKIEWICZ, M. (2000): Ocena zagospodarowania otoczenia polsko-czeskich drogowych przejść granicznych. In: Mikołajewicz, Z. [ed.]: Uwarunkowania i strategie rozwoju regionalnego $\mathrm{w}$ procesach integracji europejskiej (pp. 407-420). Opole, Polskie Towarzystwo Ekonomiczne, Uniwersytet Opolski, Komitet Przestrzennego Zagospodarowania Kraju PAN.

FURMANKIEWICZ, M. (2005): Town-twinning as a factor generating international flows of goods and people - the example of Poland. BELGEO, 1-2: 145-162.

FURMANKIEWICZ, M. (2007): International Cooperation of Polish Municipalities: Directions and Effects. Tijdschrift voor Economische en Sociale Geografie, 98(3): 349-359.

FURMANKIEWICZ, M., POTOCKI, J., KAZAK, J. (2019): Land-Use Conflicts in the Sudetes, Poland. IOP Conference Series: Materials Science and Engineering, 471(092033): 1-10.

GERBER, J., LARA, F., DE LA PARRA, C. (2010): Reimagining the U.S.-Mexico Border: Policies towards a More Competitive and Sustainable Transborder Region. Global Economy Journal, 10(4): 1-17.

HEFFNER, K. (1998): Kluczowe problemy demograficznoosadnicze obszarów przygranicznych Polska-Czechy. Opole, PIN - Instytut Śląski.

HEŁDAK, M., KEMPA, O. (2007): Current demographic changes in rural areas of south-western Poland, 19882002. Moravian Geographical Reports, 15(4): 25-30.

HOLLY, W., NEKVAPIL, J., SCHERM, I., TIŠEROVÁ, P. (2003): Unequal Neighbours: Coping with Asymmetries. Journal of Ethnic and Migration Studies, 29(5): 819-834.
ILNICKI, D. (2009): Przestrzenne zróżnicowanie poziomu rozwoju usług w Polsce. Teoretyczne i praktyczne uwarunkowania badań. Wrocław: Instytut Geografii i Rozwoju Regionalnego.

JONES, S. B. (1959): Boundary concept in the setting of place and time. Annals of the Association of American Geographers, 49(3): 241-255.

JURCZEK, P. (2002): Cross-border cooperation in the German-Czech-Polish border region at the turn of the century. Journal of Borderlands Studies, 17(2): 97-104.

KACHNIARZ, M., SZEWRAŃSKI, S., KAZAK, J. (2019): The Use of European Funds in Polish and Czech Municipalities. A Study of the Lower Silesia Voivodship and Hradec Kralove Region. IOP Conference Series: Materials Science and Engineering, 471(112047): 1-8.

KACZMAREK, T. (2006): Transborder co-operation and inter-territorial partnership of Polish communes and regions. Quaestiones Geographicae, 25(B): 61-71.

KHAN, A. M. (2010): Prediction and Display of Delay at Road Border Crossings. The Open Transportation Journal, 4: 9-22.

KISILOWSKI, J., ZALEWSKI, J. (2010): Chosen Aspects of Analysis of Road Traffic Safety in Poland between 1995 and 2008. Journal of KONBIN, 14(2010): 409-420.

KLADIVO, P., PTÁČEK, P., ROUBÍNEK, P., ZIENER, K. (2012): Czech-Polish and Austrian-Slovenian borderland - similarities and differences of development and typology of regions. Moravian Geographical Reports, 20(3): 48-63.

KNOTTER, A. (2014): Perspectives on Cross-Border Labor in Europe: '(Un)familiarity' or 'Push-and-Pull'? Journal of Borderlands Studies, 29(3): 319-326.

KOLEJKA, J., ŻYSZKOWSKA, W., BATELKOVÁ, K., CIOK, S., DOŁZBŁASZ, S., KIRCHNER, K., KREJČÍ, T., RACZYK, A., SPALLEK, W., ZAPLETALOVÁ, J. (2015): Permeability of Czech-Polish border using by selected criteria. Geographia Technica, 10(1): 51-65.

KOLOSOV, V., WIĘCKOWSKI, M. (2018): Border changes in Central and Eastern Europe: an introduction. Geographia Polonica, 91(1): 5-16.

KOMORNICKI, T. (1999): Granice Polski. Analiza zmian przepuszczalności w latach 1990-1996. Warszawa, IGiPZ PAN.

KOMORNICKI, T. (2004): Przemiany przenikalności polskich granic latach 1990-2002. Biuletyn KPZK PAN, 211: 391-406.

KOMORNICKI, T., WIŚNIEWSKI, R. (2017): Border Traffic as a Measure of Trans-Border Relations. Mitteilungen der Österreichischen Geographischen Gesellschaft, 159: 151-172.

KRAJEWSKI, P. (2019): Monitoring of Landscape Transformations within Landscape Parks in Poland in the $21^{\text {st }}$ Century. Sustainability, 11(2410): 1-22.

KRÄTKE, S. (1996): Where East meets West: The GermanPolish border region in transformation. European Planning Studies, 4(6): 647-669.

KULCZYŃSKA, K. (2018): Zachowania przestrzenne konsumentów w miastach podzielonych polskoniemieckiego i polsko-czeskiego obszaru przygranicznego. Poznań, Wydawnictwo Naukowe UAM. 
KULCZYŃSKA, K., MATYKOWSKI, R. (2008): Struktura przestrzenno-handlowa przygranicznego zespołu miejskiego Česky Těšin-Cieszyn. Dokumentacja Geograficzna, 36: 202-207.

KUROWSKA-PYSZ, J. SZCZEPAŃSKA-WOSZCZYNA, K. (2017): The Analysis of the Determinants of Sustainable Cross-Border Cooperation and Recommendations on its Harmonization. Sustainability, 9(2226): 1-24.

LADYSZ, J. (2006): Chosen aspects of sustainable development on the Polish, Czech and German borderland. GeoJournal, 67(1): 1-7.

LATOCHA, A. (2012): Changes in the rural landscape of the Polish Sudety Mountains in the post-war period. Geographia Polonica, 85(4): 13-21.

LEIMGRUBER, W. (2005): Boundaries and transborder relations, or the hole in the prison wall: On the necessity of superfluous limits and boundaries. GeoJournal, 64(3): 239-248.

MACHEK, M. (2012): Retail Market Structure Development in Central Europe. Central European Business Review, 1(3): 22-27.

MACKRÉ, Q. (2008): Regional development and geopolitics of the state borders in Poland: the implications of the EU membership. Quaestiones Geographicae, 27(1): 53-65.

MÁLIKOVÁ, L., KLOBUČNÍK, M., BAČÍK, V., SPIŠIAK, P. (2014): Socio-economic changes in the borderlands of the Visegrad Group (V4) countries. Moravian Geographical Reports, 23(2): 26-37.

MARTÍNEZ, O. J. (1994): Border People: Life and Society in the U.S.-Mexico Borderlands. Tucson, The University of Arizona Press.

MILTIADOU, M., BOUHOURAS, E., BASBAS, S., MINTSIS, G., TAXILTARIS, C. (2017): Analysis of border crossings in South East Europe and measures for their improvement. Transportation Research Procedia, 25: 603-615.

MINGHI, J. V. (1963): Boundary Studies in Political Geography. Annals of the Association of American Geographers, 53(3): 407-428.

NELLES, J., DURAND, F. (2014): Political rescaling and metropolitan governance in cross-border regions: comparing the cross-border metropolitan areas of Lille and Luxembourg. European Urban and Regional Studies, 21(1): 104-122.

NEWMAN, D. (2003a): Boundaries. In: Agnew, J., Mitchell, K. Toal, G. [eds.]: A Companion to Political Geography (pp. 123-137). Oxford, Blackwell Publishing Ltd.

NEWMAN, D. (2003b): On Borders: Theoretical Framework. Journal of Borderland Studies, 18(1): 13-25.

NEWMAN, D. (2006): Borders and Bordering. Towards an Interdisciplinary Dialogue. European Journal of Social Theory, 9(2): 171-186.

NICOL, H. N., MINGHI, J. (2005): The Continuing Relevance of Borders in Contemporary Contexts. Geopolitics 10(4): 680-687.

OLESZEK, J. (2007): Significant changes in the character and form of villages in the Złote Góry Mountains boundary region (Poland). Moravian Geographical Reports, 15(4): 37-43.
PÁSZTO, V., MACKU゚, K., BURIAN, J., PÁNEK, J., TUČEK, P. (2019): Capturing cross-border continuity: The case of the Czech-Polish borderland. Moravian Geographical Reports, 27(2): 122-138.

PAWLUSIŃSKI, R., KUBAL, M. (2015): Border twin towns in the V-4 countries: partnerships through tourism as a way of exploiting the potential of the historical and cultural heritage of towns. Central European Regional Policy and Human Geography, 5(1): 21-39.

PHILLIPS, J. D. (2005): Improving Border Management. International Journal, 60(2): 407-415.

PIPAN, P. (2007): Cross-border cooperation between Slovenia and Croatia in Istria after 1991. Acta geographica Slovenica, 47(2): 223-243.

POPESCU, G. (2011): Bordering and ordering in the twentyfirst century: Understanding borders. Lanham, Rowman \& Littlefield.

POWĘSKA, H. (2008): The Character and Conditions for Development of Cross-Border Shopping in Poland in the Period of Transformation. Electronic Journal of Polish Agricultural Universities - Economics, 11(4): 09.

POWĘSKA, H. (2016): Handel przygraniczny w warunkach zmian przenikalności granicy. Warszawa, Wydawnictwo SGGW.

POTOCKI, J., KACHNIARZ, M., PIEPIORA, Z. (2014): Sudetes - cross-border region? In: Jedlička, P. [ed.]: The International Conference Hradec Economic Days 2014. Economic Development and Management of Regions. Peer-Reviewed Conference Proceedings, Part V (pp. 191200): Hradec Králové, Gaudeamus.

PRESCOTT, J. R. V. (1965): The Geography of Frontiers and Boundaries, London: Hutchinson University Library.

PRESCOTT, V., TRIGGS, G. D. (2008): International Frontiers and Boundaries. Law, Politics and Geography. Leiden-Boston, Martinus Nijhoff Publishers.

PROKKOLA, E. K. (2010): Borders in tourism: the transformation of the Swedish-Finnish border landscape. Current Issues in Tourism, 13(3): 223-238.

PRZYBYŁA, K., KULCZYK-DYNOWSKA, A. (2017): Transformations of Tourist Functions in Urban Areas of the Karkonosze Mountains. IOP Conference Series: Materials Science and Engineering, 245(7): 1-7.

REITEL, B. (2006): Governance in Cross-border Agglomerations in Europe - The Examples of Basel and Strasbourg. Europa Regional, 14(1): 9-21.

RIETVELD, P. (2012): Barrier Effects of Borders: Implications for Border Crossing Infrastructures. European Journal of Transport and Infrastructure Research, 12(2): 150-166.

ROSIK, P. (2012): Dostępność lądowa przestrzeni Polski w wymiarze europejskim. Series: Prace Geograficzne, 233. Warszawa, IGiPZ PAN.

ROSIK, P., STEPNIAK, M., KOMORNICKI, T. (2015): The decade of the big push to roads in Poland: Impact on improvement in accessibility and territorial cohesion from a policy perspective. Transport Policy, 37: 134-146.

RYCHLÍK, J. (2016): Překračování hranic a emigrace v Československu a východní Evropě ve 20. století. Securitas Imperii, 29(2): 10-72. 
SCOTT, J.W. (2011): Reflections on EU Geopolitics: Consolidation, Neighbourhood and Civil Society in the Reordering of European Space. Geopolitics, 16(1): 146-175.

SCOTT, J. W., VAN HOUTUM, H. (2009): Guest Editorial: Reflections on EU Territoriality and the 'Bordering' of Europe. Political Geography, 28(5): 271-273.

SOHN, C. (2014): The Border as a Resource in the Global Urban Space: A Contribution to the Cross-Border Metropolis Hypothesis. International Journal of Urban and Regional Research, 38(5): 1697-1711.

SOHN, C., LARA-VALENCIA, F. (2013): Borders and Cities: Perspectives from North America and Europe. Journal of Borderlands Studies, 28(2): 181-190.

SPIERINGS, B., VAN DER VELDE, M. (2008): Shopping, Borders and Unfamiliarity: Consumer Mobility in Europe. Tijdschrift voor Economische en Sociale Geografie, 99(4): 497-505.

STRYJAKIEWICZ, T. (1998): The changing role of border zones in the transforming economies of East-Central Europe: The case of Poland. GeoJournal, 44(3): 203-213.

STUDZIŃSKA, D., SIVKOZ, A., DOMANIEWSKI, S. (2018): Russian cross-border shopping tourists in the Finnish and Polish borderlands. Norsk Geografisk Tidsskrift Norwegian Journal of Geography, 72(2): 115-126.

SZMYTKIE, R., TOMCZAK, P. (2017): Revival of rural settlements in Kłodzko Land. Geographia Polonica, 90(3): 319-333.

SZYTNIEWSKI， B. B., SPIERINGS, B., VAN DER VELDE, M. (2017): Socio-cultural proximity, daily life and shopping tourism in the Dutch-German border region. Tourism Geographies, 19(1): 63-77.

TIMOTHY, D. J. (1995): Political boundaries and tourism: Borders as tourist attractions. Tourism Management, 16(7): 525-532.
TIMOTHY, D. J., GELBMAN, A. (2015): Tourist lodging, spatial relations, and the cultural heritage of borderlands. Journal of Heritage Tourism, 10(2): 202-212.

TURNOCK, D. (2002): Cross-border cooperation: A major element in regional policy in East Central Europe. Scottish Geographical Journal, 118(1): 19-40.

TWARDZIK, M., HEFFNER, K. (2019): Small Towns and Rural Areas - as a Prospective Place of Modern Retail Trade Formats in Poland. European Countryside, 11(1): 74-84.

VAISHAR, A., DVOŘÁK, P., HUBAČÍKOVÁ, V., ZAPLETALOVÁ, J. (2013): Contemporary development of peripheral parts of the Czech-Polish borderland: case study of the Javorník area. Geographia Polonica, 86(3): 237-253.

VAN DER VELDE, M., SPIERINGS, B. (2010): Consumer Mobility and the Communication of Difference: reflecting on Cross-Border Shopping Practices and Experiences in the Dutch-German Borderland. Journal of Borderlands Studies, 25(3-4): 191-205.

VAN HOUTUM, H. (1999): Internationalisation and mental borders. Tijdschrift voor Economische en Sociale Geografie, 90(3): 329-335.

VAN HOUTUM, H., VAN NAERSSEN, T. (2002): Bordering, Ordering and Othering. Tijdschrift voor Economische en Sociale Geografie, 93(2): 125-136.

WIECKOWSKI, M. (2010): Tourism development in the borderlands of Poland. Geographia Polonica, 83(2): 67-81.

YODER, J.A. (2003): Bridging the European Union and Eastern Europe: Cross-border cooperation and the Euroregions. Regional and Federal Studies, 13(3): 90-106.

Please cite this article as:

FURMANKIEWICZ, M., BURYŁO, K., DOŁZBŁASZ, S. (2020): From service areas to empty transport corridors? The impact of border openings on service and retail facilities at Polish-Czech border crossings. Moravian Geographical Reports, 28(2): 136-151. Doi: https:// doi.org/10.2478/mgr-2020-0011 